\title{
Investigation into the Application of Cissus Populnea as Drilling Fluid Additive (Viscosifier) for Water Based Mud
}

\author{
A. D. I. Sulaiman, M. B. Adamu, Usman Hassan, and S. M. Aliyu
}

\begin{abstract}
Progress in drilling engineering demands more sophistication from the drilling mud in order to enhance the usage of drilling fluids, hence numerous additives were introduced, and a simple fluid became a complicated mixture of liquid, solid and chemicals. Some of the challenges with the existing drilling fluid additives has to do with compatibility, degradability, safety, cost, and environmental friendliness. Studies have been carried out on the economic benefits of $\mathrm{Cissus}$ Populnea which includes in areas of food, medicine, shelter, and transport but much attention has been paid to its applications in the Oil and Gas industry. This study investigates the rheological properties of Cissus Populnea for application as drilling fluid additive (viscosifier) in Water Based Drilling Mud. Fresh roots, stems and leaves of cissus populnea were sourced from Bayara, Bauchi State. Some liquid exudates of cissus populnea were collected and stored for analysis while some of the samples were dried and grinded in to powdered form. Exudate of the samples were characterized by FTIR, XRD and XRF. Drilling mud was formulated with the samples cisssus populnea and bentonite at different temperatures. The rheology of the formulated drilling mud was investigated and compared with that formulated using bentonite and carboxymethyl cellulose (CMC). Results from Xray Fluorescence analysis show that the chemical composition of Cissus populnea stem and root are similar when comparing their major components $\left(\mathrm{In}_{2} \mathrm{O}_{3}\right.$ and $\left.\mathrm{CaO}\right)$, while that of leaf has its major components to be $\mathrm{In}_{2} \mathrm{O}_{3}$ and $\mathrm{Cl}$. Therefore, in this research work, experiments were conducted with only stem and leaf since stem and roots have common features. From the results of FTIR spectra, the stem of cissus populnea has an $\mathrm{OH}$ peak wavelength of $3487.42 \mathrm{~cm}^{-1}$ while that of leave is $3340.82 \mathrm{~cm}^{-1}$. The diffractogram of the stem of cissus populnea was observed at $2 \theta=22.67^{\circ}$ which is very close to that of CMC $\left(2 \theta=20.31^{\circ}\right)$ while the intense peaks of leaf were observed at around $28.65^{\circ}$. Viscosity of cissus populnea was investigated and found to be decreasing with the increase in temperature for stem exudate. While for leaf exudate, the viscosity was rather increasing with the increase in temperature at temperatures below $35^{\circ} \mathrm{C}$ and then continue to decrease with the increase in temperature. The outcome of this research has confirmed the applicability of cissus populnea for drilling fluid additives, viscosifier.
\end{abstract}

Key words - Cissus Populnea, Drilling Fluid Additive, WaterBased Mud and CMC.

\section{INTRODUCTION}

With the increasing uncertainty in the price of crude oil and gas, increase in search for alternative energy sources and ever

Submitted on September 27, 2021

Published on November 14, 2021.

A. D. I. Sulaiman, Department of Petroleum Engineering, Abubakar

Tafawa Balewa University, Nigeria.

(e-mail: alhajidodo@ gmail.com)

M. B. Adamu, Department of Petroleum Engineering, Abubakar Tafawa

Balewa University, Nigeria.

(e-mail: belloadmu@gmail.com) increasing stiff environmental challenges and regulations, the hydrocarbon industry captains continue to search for a more cost effective and environmentally friendly ways of carrying out drilling operations. Drilling is one of the capital-intensive activities of oil and gas business. Interestingly, most of the materials needed for drilling operations (from machineries, equipment down to consumables) are mostly imported from foreign countries. Consequently, the cost of drilling operations continues to rise despite uncertainty in the prices of the produced products [1].

The plant cissus populnea is a food gum, edible and of high medicinal use. It contains about $79 \%$ carbohydrate, $11 \%$ moisture, $3 \%$ crude protein, and $3 \%$ crude fiber [2]. It is also known for its gelliness and firmness. The drilling mud must possess some rheological characteristics for it to perform it functions properly; many of these characteristics are controlled and modulated by additives that can improve the mud characteristics as may be required during drilling operations. Factors such as rheology, filtration control, and temperature stability are all integral to the performance selection process and are incorporated in the test procedure to best reflect the actual field conditions for drilling operations The cissus populnea's natural rheological characteristics such as its gelliness are suspected to be able to increase the gel strength, mud density and viscosity to an appreciable condition, which can eventually improve the overall drilling performance. Water based mud is the mostly used drilling fluid for the onshore and offshore drillings, probably because it is environmentally friendly and cheaper compared to the other drilling fluids. Therefore, water soluble polymers are always the first choice in drilling fluids [3]. In addition to high cost of synthetic polymers which may not allow fair playground for our local business partners, some of the synthetic polymers may react with calcium, and may cause high viscosity and gelation of the drilling mud. On the other hand, natural polymers are able to absorb water and increase the viscosity of water due to their molecular sizes and shapes [4], [5]. Natural polymers are nontoxic, soluble in water, has the ability to form gel, and posse no charge capacity and therefore may not reach to calcium or any other formation fluids [6]. Biodegradation of additives is a key environmental performance indicator used by many regulators as a classification tool to grant a pass/fail status to a product or used in ranking a system [7]. Typically, an aerobic seawater

Usman Hassan, Department of Petroleum Engineering, Abubakar Tafawa Balewa University, Nigeria.

(e-mail: shingasco ${ }^{@}$ gmail.com)

S. M. Aliyu, Department of Petroleum Engineering, Abubakar Tafawa Balewa University, Nigeria.

(e-mail: suleialiyu010@gmail.com) 
test such as OECD 306, or and anaerobic seawater test such as ISO 11734 is used [2]. Environmental and technical performance of drilling fluid additives is the key characteristic of the product [8]. But sometimes materials that show good technical performance (stability) at high temperatures are poor biodegraders, while those that are most chemically active can show the highest toxicity [2], [9].

Many indigenous polymers have become very popular for their use in drilling fluid due to their ability to modify rheological properties of clay suspension and their environmental friendliness. The common challenges experienced are excessive fluid loss, low gel strength and the need to formulate a fluid with desirable rheological properties to withstand increasing temperature and pressure conditions.

\section{MATERIALS AND METHOD}

Cissus populnea was sourced from Bayara, Bauchi State, Nigeria. Bentonites and CMC was sourced from an oil company currently operating in Niger Delta, Nigeria. Other consumables for the experiment were sourced from different shops and laboratories across Bauchi and Jos metropolis. Some of the equipment used were from the department of petroleum engineering, Abubakar Tafawa Balewa University, Bauchi while most of other experiments were carried out commercially from other research institution, outside ATBU.

\section{EXPERIMENTS}

The phytochemical constituents of the extracted liquor have been reported and used in ethnomedicine for treatment of male infertility [1]. As shown in Table I, food gum plant contains more than $60 \%$ cellulose and about $15 \%$ Hemicelluloses by weight.

\begin{tabular}{cc} 
TABLE I: PROXIMATE COMPOSITION OF C. POPULNEA FIBERS [10] \\
\hline Composition & percentage $(\mathrm{w} / \mathrm{w} \%)$ \\
\hline Moisture & $3.94 \pm 0.23$ \\
Dry matter & $96.06 \pm 0.2$ \\
Ash & $1.59 \pm 0.14$ \\
Wax & $2.94 \pm 0.31$ \\
Water soluble & $2.33 \pm 0.27$ \\
Pectins & $1.14 \pm 0.03$ \\
Lignins & $11.52 \pm 0.27$ \\
Hemicellulose & $14.74 \pm 0.42$ \\
Celluloses & $61.80 \pm 0.45$ \\
\hline
\end{tabular}

\section{A. Sample Preparation}

The samples of Cissus populnea used for this study were obtained from Bauchi state in its fresh form. The samples were thoroughly washed and divided in to two groups (Grp1 \& Grp2). For the Grp1, stems were cut into pieces and leaves were plugged and all dried under sun for 21 days. The number of days to dry the samples depend on the weather condition (temperature), the experiment was carried out. The sample was not oven dried because there is the need to preserve its physical property and morphology, to certain extent. The dried samples were grounded into powder using mortal and pistil figures. For samples Grp2, stems of cissus populnea were cleaned and chopped into pieces, pound for a few minutes and soaked in warm water of temperature of $60{ }^{\circ} \mathrm{C}$ and allowed for 30 minutes. The strips were sieved under the water and the exudates was collected. The fresh leaves were pounded for just 5 minutes and exudates also collected, using the same process. The collected gums were stored in the freezer for further analysis.

In order to get the exudates of the cissus populnea, fresh stems were cut into smaller sizes and poured into mortal and pounded for 15 minutes, after which $350 \mathrm{ml}$ of distilled water was added to the sample. The sample was then filtered using a sieve, after which exudates of the sample was collected. Also, the fresh leaves were pounded for just $5 \mathrm{~min}$ and 350 $\mathrm{ml}$ of distilled water was added, and the sample was sieved, and the exudates collected. Characterization of powdered Cissus populnea samples were carried out using FTIR, XRF and XRD. The results of FTIR are shown in Fig. 2 and 3, that of XRF in Fig. 5 and 6 while for XRD in Tables I, II and III.

\section{B. Rheology and Filtration}

Experiments on determination of specification for drilling fluids materials was carried out for both the CMC and samples Grp1 samples using the API standard (API specification 13A/ISO 13500). Drilling fluids were formulated with the samples and bentonite. Their rheological properties were determined and compared with that of drilling fluid formulated using the $\mathrm{CMC}$ and bentonite. A conventional 35 viscometer was used to generate mud parameters such as plastic viscosity (PV), yield point (YP) and gel strength. The formulated drilling fluid was allowed to age for $16 \mathrm{~h}$. The viscometer measures the torque under 8 different rotational speeds, ranging from 600 to $3 \mathrm{rpm}$. Equations (1)-(3) were then used to translate these readings to plastic viscosity (PV), apparent viscosity (AV) and Yield point (YP).

$$
\begin{aligned}
& P V=\theta_{600}-\theta_{300}(\text { in } c p) \\
& A V=\frac{\theta_{600}}{2} \\
& Y P=\theta_{300}-P V\left(\text { in } \frac{l b}{100 f t}\right)
\end{aligned}
$$

where PV, AV and YP are plastic viscosity, apparent viscosity and yield point respectively. $\theta_{600}$ is the dial reading at $600 \mathrm{rpm}$ and $\theta_{300}$ is the reading at $300 \mathrm{rpm}$.

The $\mathrm{p}^{\mathrm{H}}$ and mud weight were carried out using a digital $\mathrm{p}^{\mathrm{H}}$ meter (model Ohaus Portable $\mathrm{p}^{\mathrm{H}}$ Meter with Buffer Solution Power) and mud balance respectively, in accordance with the API chemical tests. API filtrate and gel $(3 \mathrm{rpm}$ dial reading after 10 seconds and 10 min of mixing were determined using API recommendations.

Mud filtrate is the liquid portion of the mud system that is driven through a filter cake into the formation by the difference between the hydrostatic pressure of the mud column and the formation pressure. It was measured with Victor model 1225 filter press. Mud passes through a filter paper at $100 \mathrm{psi}$ and filter volume after 10 second and 10 minutes of filtration were recorded. The pressure was provided by a cartridge containing pressurized carbon dioxide. The mud was prepared with high speed mixer. 


\section{Effect of Temperature}

Three hundred and fifty milliliters $(350 \mathrm{ml})$ each of samples of stem and leaves were heated from ambient temperature of $28.1{ }^{\circ} \mathrm{C}$ to $80{ }^{\circ} \mathrm{C}$ in a calorimeter cup using Water bath Model DK - 420 (Medifield Equipment \& Scientific Ltd England). The viscosity reading was taken at the interval of 10 minutes, except for the first one which was taken at the interval of 2 minutes, until the temperature of $80{ }^{\circ} \mathrm{C}$ was attained.

\section{RESULTS AND DISCUSSION}

FTIR Fourier Transform Infrared Spectroscopy (FTIR) indicates chemical changes in the polymer structure. The $\mathrm{x}$ axis represents the wavelength $\left(\mathrm{cm}^{-1}\right)$ and $y$-axis is the light transmittance through the sample. Cellulose and carboxymethyl have similar functional groups with same absorption bands in FTIR such as hydroxyl groups (-OH stretching) at 3200-3600 $\mathrm{cm}^{-1}$, hydrocarbon groups (-CH2 scissoring) at $1450 \mathrm{~cm}^{-1}$, carbonyl groups $(\mathrm{C}=\mathrm{O}$ stretching $)$ at $1600 \mathrm{~cm}^{-1}$ and ether groups (-O-) at $1000-1200 \mathrm{~cm}^{-1}$, also C$\mathrm{H}$ stretching vibration at $3000 \mathrm{~cm}^{-1}$. The FTIR spectra of CMC sample (Fig. 2) showed the emblematic absorptions of the cellulose backbone as well as the presence of the carboxyl, $\mathrm{C}=\mathrm{O}$ group at $3427 \mathrm{~cm}^{-1}$. From the results of FTIR spectra of stems and leaves of cissus-populnea (Fig. 3 and 4), it can be seen that stems have a peak of wavelength to be $3487.42 \mathrm{~cm}^{-1}$ which is closer to that of CMC, while that of leave is $3340.82 \mathrm{~cm}^{-1}$. Thus, stems of cissus-populnea has a closer property to $\mathrm{CMC}$ than that of the leaves.

The broad band located within the region of 3500 $3200 \mathrm{~cm}^{-1}$ appeared in the spectra of leaf indicates the free $\mathrm{OH}$ stretching vibration as well as inter- and intramolecular hydrogen bonds in cellulose molecules [5].

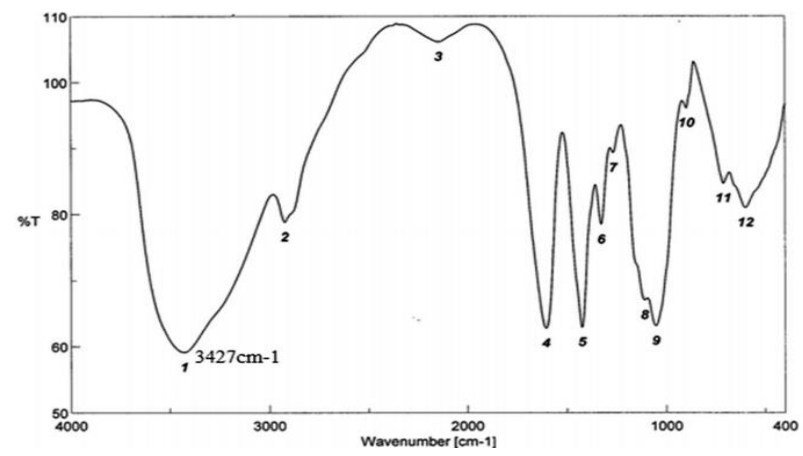

Fig. 1. FTIR Spectrum for Carboxymethylcellulose (CMC) [11]

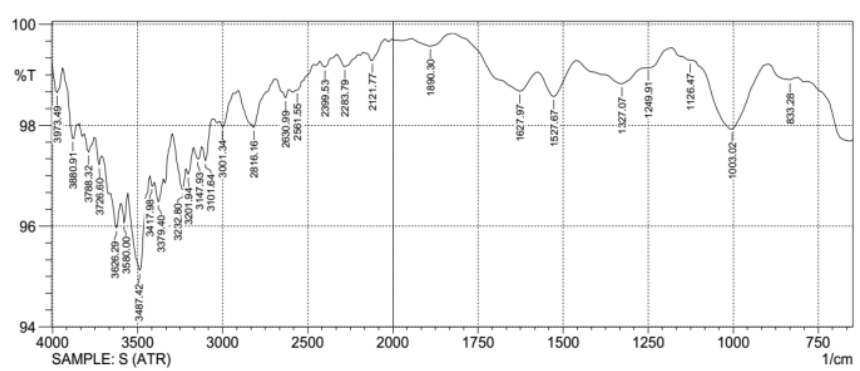

Fig. 2. FTIR Spectrum for Cissus Populnea Stem.

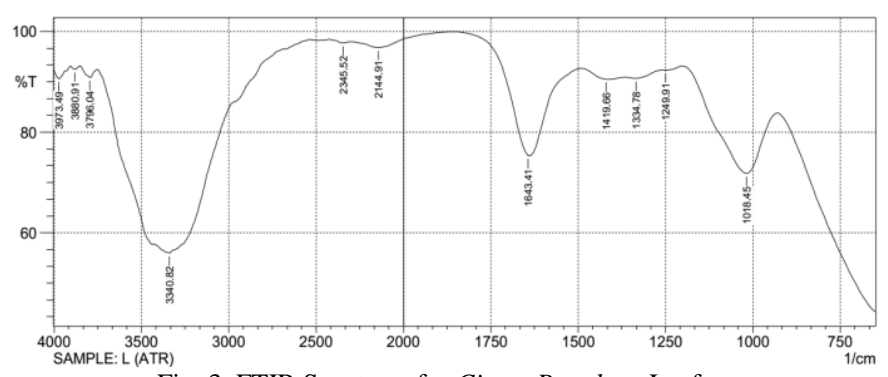

Fig. 3. FTIR Spectrum for Cissus Populnea Leaf.

\section{A. X-Ray Diffraction (XRD) Analysis}

Fig. 4 shows the X-ray diffraction pattern, in which the typical peak of cellulose and carboxymethyl cellulose are observed. CMC has a main characteristic peak at $2 \theta=20.31^{\circ}$ which was described to have less crystalline due to the cleavage of hydrogen bonds from $\mathrm{NaOHi}$.

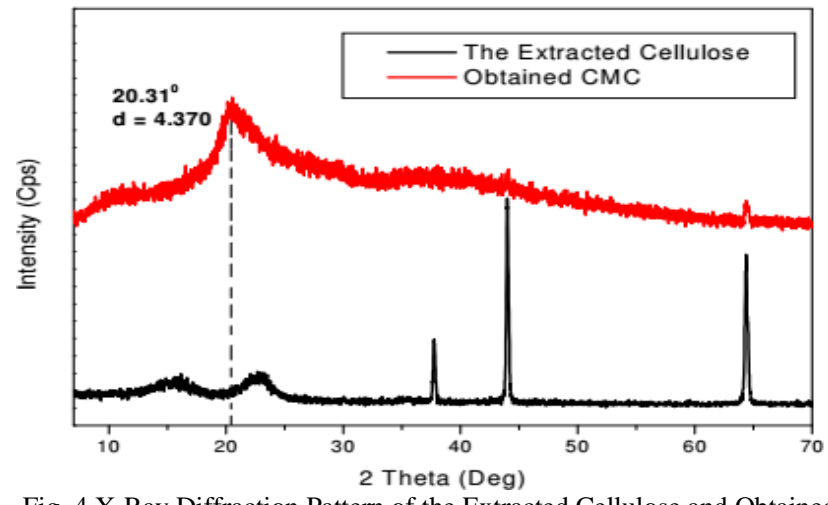

Fig. 4 X-Ray Diffraction Pattern of the Extracted Cellulose and Obtained CMC [13].

Fig.4 showed the diffractogram of the stem of cissus populnea observed at $2 \theta=22.67^{\circ}$. This looks similar to that of CMC. While the intense peaks of leaf were observed around $28.65^{\circ}$ (Fig. 6) which is not very close to that of CMC but is also related.

\section{B. X-ray Fluorescence}

$\mathrm{X}$-ray fluorescence $(\mathrm{XRF})$ is an analytical technique that can be used to determine the chemical composition of a wide variety of sample types including solids, liquids, slurries and loose powders. X-ray fluorescence is also used to determine the thickness and composition of layers and coatings. It can analyze elements from beryllium (Be) to Uranium (U) in concentration ranges from $100 \mathrm{wt} \%$ to sub-ppm levels. Tables I, II and III below show the results of X-ray Fluorescence for cissus populnea stem, leaves and root respectively. It could be observed, from X-ray Fluorescence analysis, that the chemical composition of Cissus populnea stem and root are similar when comparing their major components $\left(\operatorname{In}_{2} \mathrm{O}_{3}\right.$ and $\mathrm{CaO}$ ), while that of leaf has a little deviation which has its major components to be $\operatorname{In}_{2} \mathrm{O}_{3}$ and $\mathrm{Cl}$. 




Counts

Fig. 5. X-Ray Diffraction of Cissus Populnea Stem.

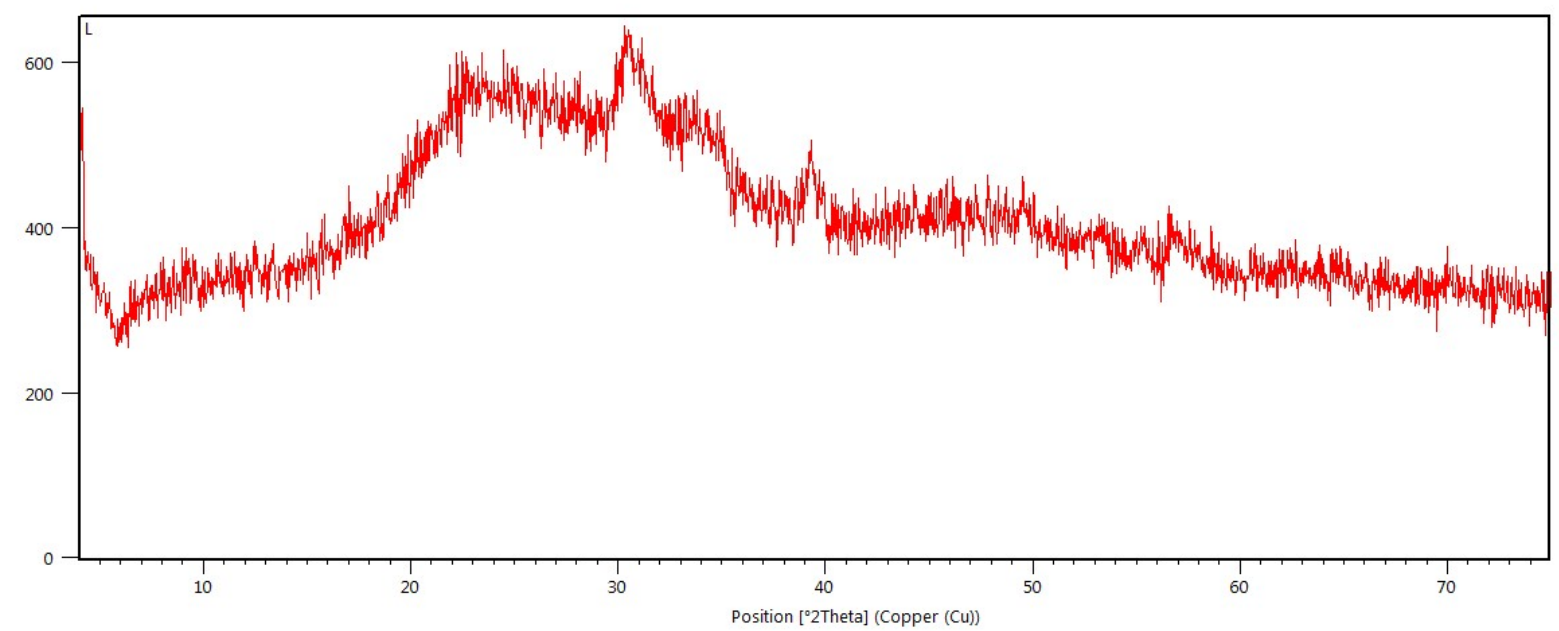

Fig. 6 X-Ray Diffraction of Cissus Populnea Leaf.

TABLE II: X-RAY FLUORESCENCE ANALYSIS OF CISSUS POPULNEA STEM

\begin{tabular}{ccccccccccccccc}
\hline Compd & $\mathrm{Cl}$ & $\mathrm{CaO}$ & $\mathrm{TiO}_{2}$ & $\mathrm{MnO}$ & $\mathrm{FE}_{2} \mathrm{O}_{3}$ & $\mathrm{NiO}$ & $\mathrm{CuO}$ & $\mathrm{ZnO}$ & $\mathrm{Br}$ & $\mathrm{SrO}$ & $\mathrm{RuO}$ \\
\hline Conc unit & $3.75 \%$ & $24.6 \%$ & $0.04 \%$ & $0.06 \%$ & $1.28 \%$ & $0.098 \%$ & $0.33 \%$ & $0.12 \%$ & $0.11 \%$ & $0.799 \%$ & $3.8 \%$ \\
\hline Compd & $\mathrm{BaO}$ & $\mathrm{Eu}_{2} \mathrm{O}_{3}$ & $\mathrm{Er}_{2} \mathrm{O}_{3}$ & $\mathrm{Yb}_{2} \mathrm{O}_{3}$ & $\mathrm{Re}_{2} \mathrm{O}_{7}$ & $\mathrm{IrO}_{2}$ & $\mathrm{CuO}$ & $\mathrm{Au}_{2}$ & $\mathrm{Tl}_{2} \mathrm{O}_{3}$ & $\mathrm{PbO}_{2} \mathrm{In}_{2} \mathrm{O}_{3}$ \\
\hline Conc unit & $0.2 \%$ & $0.3 \%$ & $0.49 \%$ & $0.00 \%$ & $0.1 \%$ & $0.33 \%$ & $0.33 \%$ & $0.42 \%$ & $0.25 \%$ & $0.38 \%$ & $62.4 \%$ \\
\hline
\end{tabular}

TABLE III: X-RAY FLUORESCENCE ANALYSIS OF CISSUS POPULNEA LEAF

\begin{tabular}{ccccccccccc}
\hline Compd & $\mathrm{Cl}$ & $\mathrm{CaO}$ & $\mathrm{Fe}_{2} \mathrm{O}_{3}$ & $\mathrm{CuO}$ & $\mathrm{ZnO}$ & $\mathrm{GeO}_{2}$ & $\mathrm{ln}_{2} \mathrm{O}_{3}$ & $\mathrm{Re}_{2} \mathrm{O}_{7}$ & $\mathrm{PtO}_{2}$ & $\mathrm{PbO}$ \\
\hline Conc unit & $23.0 \%$ & $2.0 \%$ & $1.4 \%$ & $1.7 \%$ & $0.3 \%$ & $0.1 \%$ & $66.4 \%$ & $1.6 \%$ & $1.6 \%$ & $1.9 \%$ \\
\hline
\end{tabular}

TABLE IV: X-RAY FLUORESCENCE ANALYSIS OF CISSUS POPULNEA ROOT

\begin{tabular}{ccccccccccc}
\multicolumn{1}{c}{ TABLE IV: X-RAY FLUORESCENCE ANALYSIS OF CISSUS POPULNEA ROOT } \\
\hline Compd & $\mathrm{SO}_{3}$ & $\mathrm{Cl}$ & $\mathrm{K}_{2} \mathrm{O}$ & $\mathrm{CaO}$ & $\mathrm{Fe}_{2} \mathrm{O}_{3}$ & $\mathrm{CuO}$ & $\mathrm{Ga}_{2} \mathrm{O}_{3}$ & $\mathrm{ZnO}_{2}$ & $\mathrm{As}_{2} \mathrm{O}_{3}$ & $\mathrm{ZrO}_{2}$ \\
\hline Conc unit & $0.48 \%$ & $2.87 \%$ & $6.1 \%$ & $15.7 \%$ & $1.99 \%$ & $0.24 \%$ & $0.081 \%$ & $0.15 \%$ & $0.22 \%$ & $0.38 \%$ \\
\hline Compd & $\mathrm{BaO}$ & $\mathrm{Sb}_{2} \mathrm{O}_{3}$ & $\mathrm{CeO}_{2}$ & $\mathrm{Eu}_{2} \mathrm{O}_{3}$ & $\mathrm{Er}_{2} \mathrm{O}_{3}$ & $\mathrm{Re}_{2} \mathrm{O}_{7}$ & $\mathrm{OsO}_{4}$ & $\mathrm{RuO}_{2}$ & $\mathrm{In}_{2} \mathrm{O}_{3}$ & \\
\hline Conc unit & $0.26 \%$ & $18.2 \%$ & $0.25 \%$ & $0.65 \%$ & $0.24 \%$ & $0.27 \%$ & $0.07 \%$ & $1.5 \%$ & $62.4 \%$ & \\
\hline
\end{tabular}

\section{Effect of Temperature on the Viscosity}

The apparent viscosity of cissus populnea exudates decrease with the increasing in temperature between 28.1$80{ }^{\circ} \mathrm{C}$, for leaf exudate (Table III and Fig. 7). This has contradicted the findings of some authors [13] that the apparent viscosity of cissus populnea exudate increases with the increase in temperature between $20-60{ }^{\circ} \mathrm{C}$. However, for exudate of stem, temperatures $28.1-30{ }^{\circ} \mathrm{C}$, there was no decrease in the apparent viscosity until after $35^{\circ} \mathrm{C}$, before apparent viscosity start to decrease with increasing temperature (Fig. 7). This can be explained using the explanation by the previous author [13] where it was said that such behavior is due to its system of binding.

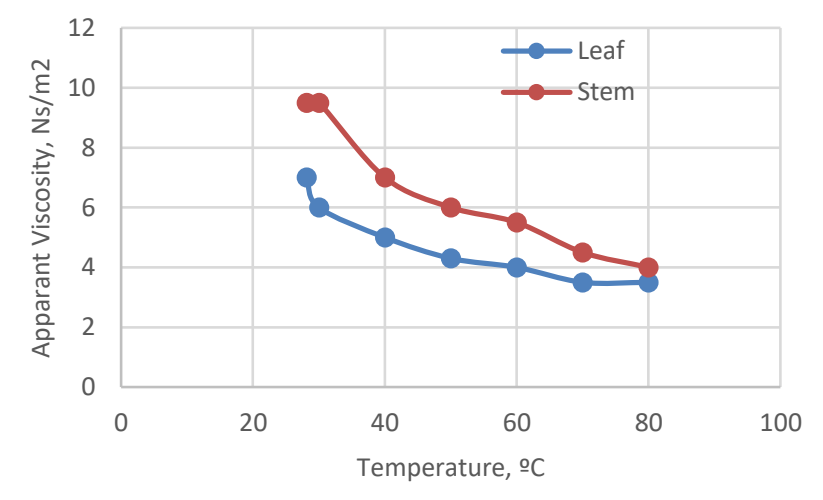

Fig. 7. Apparent viscosity versus Temperature. 


\section{CONCLUSION}

From the investigation carried out on the application of cissus populnea for use as drilling fluid viscosifying agent, the following conclusion were drawn:

1. Cissus populnea exhibit similar rheological properties to that of CMC which indicate that cissus populnea could be used as Water -Based Drilling Fluid Additive (viscosifier).

2. Apparent viscosity decreases with the increase in temperature for leaf exudate while it remained unchanged in the case of stem exudate until after $35^{\circ} \mathrm{C}$, where it decreases with the increase in temperature. This might be due to its binding system.

3. X-ray fluorescence (XRF) analysis of cissus populnea showed that stem and root exudates have similar major elements.



Plate 1. Cissus populnea leaves.

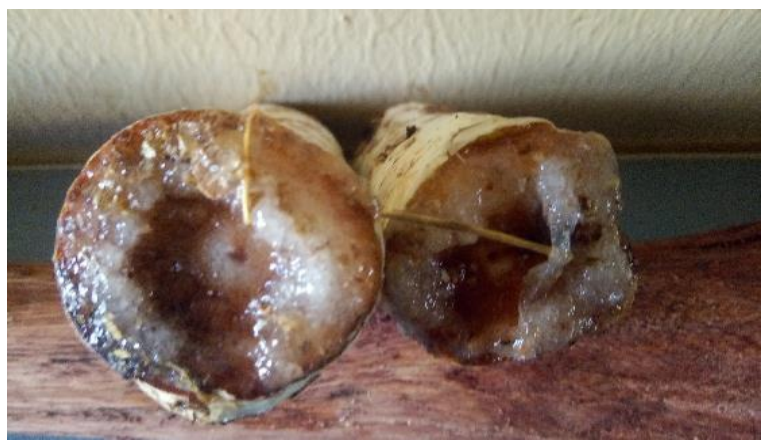

Plate 2. Cissus populnea fresh stems.

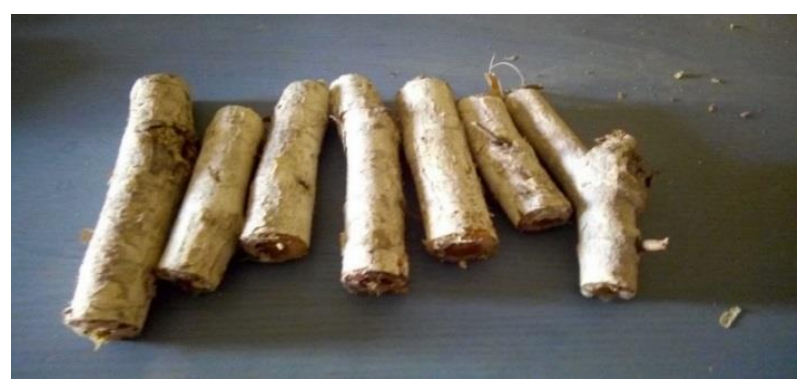

Plate 3. Cissus populnea dried stem.

\section{ACKNOWLEDGEMENT}

The Authors wish to acknowledge the TETFund for providing the finances for this research work. Our endless appreciation goes to the management of Abubakar Tafawa Balewa University Bauchi, through which the fund was provided for the research and for their endless support for the research. The team also wishes to thank the staff of laboratories of Petroleum Engineering Departments for making the laboratory spaces and some equipment available for conducting this research. Finally, team also thank the Director and all staff of Directorate of Research and Innovation of Abubakar Tafawa Balewa University for facilitating the research.

\section{REFERENCES}

[1] V. Mahto, and V. P. Sharma. Rheological Study of a Water Based Oil Drilling Fluid. Journal of Petroleum and Science Engineering, vol. 45, no.1, pp. 123-128, 2004.

[2] J. S. Alakali, S. V. Irtwange, and M. Mkavga. Rheological Characteristics of Food Gum (Cissus populnea). Afrcan Journal of Food Science, vol. 3(9) pp. 237 -242, 2009.

[3] F. Owuno, J. Eke-Ejiofor, and G. Wordu. Effects of cissus populnea gum on dough rheology and quality of wheat-cassava composite bread. Journal of Food, Agriculture \& Environment, vol. 10 (2), pp. 80-84, 2012.

[4] A. I. Igbafe, T. K. Olamiji, and A. D. I. Sulaiman. Investigating the Rheological Properties of Cissus populnea as drilling fluid additives. International Conference on Multi-disciplinery Innovation and Technology Transfer, Uniben, 2015.

[5] V. Pushpamalar, S.J. Langford, M. Ahmad, and Y.Y. Lim. Optimization of reaction conditions for preparing carboxymethyl cellulose from sago waste. Carbohydrate Polymers, vol. 64, pp. 312 318, 2006.

[6] A. Arinkoola, O. T. Salawudeen, O. K. K. Salam, M. O. Jimoh, G. O. Abidemi, and Z. M. Atitebi. Optimization of Water-Based Drilling Fluid Produced Using Modified Nigerian Bentonite and Natural Biopolymers: Reduced Experiment and Response Surface Methodology. Iranian Journal of Chemical Engineering, vol. 16, no. 1 (Winter 2019), IAChE

[7] J. Hall. Designing the Perfect drilling fluid additives: Can it be done? Paper presented at SPE, Asia Pacific Health, Safety and Environment Conference and exhibition held in Kuala Lumpur, Malaysia, 19-20, 2005.

[8] J. Zheng, J. Wang, O. M. Musa, D. Farrar, B. Cockcroft, A. Robinson et al. Innovative Chemistry for Drilling Fluid Additive. International Specialty Product (ISP). A paper presented at the SPE Middle Oil and Gas Show and Conference held in Manama, Bahrain, $25^{\text {th }}-28^{\text {th }}$ September, 2011.

[9] J. S. Alakali, S. V. Irtwange and M. Mkavga. Rheological Characteristics of Food Gum (Cissus populnea). African Journal of Food Science, vol. 3(9). pp. 237-242, 2009.

[10] O.A. Akeem, T. O. Salawudeen, K. S. Kazeem, M. O. Jimoh, O. G. Azeez. Potential Evaluation and Optimization of Natural Biopolymers in Water-Based Drilling Mud. Journal of Chemical and Petroleum Engineering, vol. 52 (1), pp. 1-12, 2018.

[11] A. Hebeish and S. Sharaf. Novel Nanocomposite Hydrogel for wound dressing and other medical applications. Article in RSC Advances 2015. DOI: 10.1039/C5RA07076G.

[12] F. K. Siregar, D. Y. Nasution, Y. Muis and D. Y. Kaban. Preparation and Characterization of Antibacterial Film Based on Carboxylmethylcellulose from Gebang leaf (Coryphautan), Polyvynil Alcohol and Citric Acid. RASAYAN J. Chemical, vol. 12, no.2, pp. 554 564.

[13] M. O. Iwe, and C. Atta. Functional Properties of the Active Ingredients of C. populnea. Crill. Perr. pp. 29-53, 1993. 